УДК 331.5:338.1

Яловий Г.К.

доктор економ. наук, професор Національний технічний університет Украйни «КПI»

\title{
ТЕОРІЯ ЛЮДСЬКОГО КАПІТАЛУ ЯК МЕТОДОЛОГІЯ ФОРМУВАННЯ ІННОВАЦІЙНОЇ СИСТЕМИ
}

\section{ТЕОРИЯ ЧЕЛОВЕЧЕСКОГО КАПИТАЛА КАК МЕТОДОЛОГИЯ ФОРМИРОВАНИЯ ИННОВАЦИОННОЙ СИСТЕМЫ}

\section{THE HUMAN CAPITAL THEORY AS THE METHODOLOGICAL BASE OF INNOVATION SYSTEM FORMATION}

На основі аналізу робіт представників класичної політичної економії, неокласичної та інституиіональної теорій визначено передумови формування людського капіталу як наукової концепиії. Розкрито ключові концептуальні положення теорії людського капіталу, а також виділено методологічні основи иієї концепџії, щуо полягають, зокрема, у використанні принципів рачіональності, синергізму, методологічного індивідуалізму. Зважаючи стратегічну мету людських ресурсів у забезпеченні конкурентоспроможності економіки Украӥни, зроблені висновки, щцо теорія людського капіталу являє собою методологічну основу управління інновачійною діяльністю, яка забезпечить підвищення конкурентоспроможності України в умовах глобалізації.

Ключові слова: теорія людського капіталу, відтворення і розвиток людського капіталу, освіта, конкурентоспроможність, закон Стівенсона-Уайдлера, інноваційна політика, інноваційна система, відкриті інновації.

На основе анализа работ представителей классической политической экономии, неоклассической и институцииональной теорий определены предпосылки формирования человеческого капитала как научной концепщии. Раскрыты ключевые концептуальные положения теории человеческого капитала, а также выделены методологические основы этой концепции, которые заключаются, в частности, в использовании принципов раџиональности, синергизма, методологического индивидуализма. Учитывая стратегическую цель человеческих ресурсов в обеспечении конкурентоспособности экономики Украины, сделанные выводы, что теория человеческого капитала являет собой методологическую основу управления инновационной деятельностью, которая обеспечит повышение конкурентоспособности Украины в условиях глобализащии.

Ключевые слова: теория человеческого капитала, воссоздания и развитие человеческого капитала, образование, конкурентоспособность, закон СтивенсонаУайдлера, инновационная политика, инновационная система, открытые инновации.

Based on the classic politeconomists, neoclassics and institutionalists groundwork analysis, there were defined the preconditions of the human capital theory forming as a science concept. The human capital theory main conceptual statements were uncovered and its methodological bases, consisting, as well, of rationality, synergy and methodological individuality principles application, were distinguished. Considering the strategic purpose of human resources 
in procurement of Ukraine's economy competitiveness, there was concluded that, the human capital theory could be displayed as the methodological base of innovation activity regulation in the light of the state competitiveness improvement.

Key words: human capital theory, reproduction and development of human capital, education, qualification, competitiveness, innovation policy, Stevenson-Wydler Act, innovation system, open innovation.

Вступ. В сучасних умовах господарювання конкурентоспроможність підприємств України в цілому на світовому ринку може бути вирішена тільки стабільними темпами переходу до інноваційної моделі економіки, яка набуває новий вигляд, тому що в іiі структурі визначальною стає не матеріальноспоживча вартість капіталу, а інтелектуальна власність. Центральне місце у такій системі займає людський капітал. Як економічна концепція теорія людського капіталу акцентує увагу на необхідності інвестування в людину та розвиток іiі здібностей для забезпечення основи стійкого економічного зростання. Виділення фактора «людський капітал» дає можливість ідентифікувати принципово важливе джерело економічного зростання, яким $\epsilon$ знання і компетенція, і відповідно, позитивно визначити економічну роль освіти, науки, охорони здоров'я та інших нематеріальних галузей людської діяльності, які до цього розглядалися як невиробничі. Теорія людського капіталу означає не тільки усвідомлення вирішальної ролі людини у економічній системі суспільства, але й призначення необхідності інвестування у людину, яка збільшує свої виробничі можливості, тобто сприяти розвитку його як працівника. Основним видом таких інвестицій є витрати на освіту (загальну і спеціальну), формальне навчання, його професійну підготовку за місцем роботи. Дослідження продуктивних сил людини, визначення можливостей спрямування іiі здібностей для збільшення добробуту та національного багатства $€$ сьогодні актуальними завданнями економічної науки.

Проблеми розвитку людського капіталу досліджені в роботах західних вчених Г. Беккер, Х. Боуен, Дж. Кендрик, Дж. Мінцер, Л. Туроу, Т. Шульц, I. Фішер тощо. Серед російських вчених треба відмітити праці О. Добриніна, С. Дятлова, С. Курчанського, Р. Нуреєва, Р. Капелюшнікова, М. Критського, С. Циренова та інших. Значних результатів у дослідженні ролі та проблем формування людського капіталу досягли українські вчені серед яких В. Антонюк, Д. Богиня, О. Бородіна, 3. Варналій, О. Грішнова, В. Геєць, О. Лібанова, Л. Лісогор, Л. Семів, Л. Тертична, О. Шевчук та інші. Західні дослідники заклали базові і методологічні засади проблеми, а вітчизняні розширили світовий досвід на рівні застосування, формування та відтворення людського капіталу у рамках національної економіки.

В зв'язку з цим набуває актуальність дослідження сукупності не уречевлених факторів в умовах економічного зростання - навчальних, 
інтелектуальних, інформаційних, організаційних, мотиваційних ресурсів, погляд на людину як на головний забезпечуючий та якісно невичерпаний ресурс економічного зростання нового типу, а також як ціль цього зростання. Сучасне бачення поступового суспільного розвитку відводить людині центральне місце у процесі економічного відтворення, виходячи 3 того, що людина як особистість $€$ i вхідним, i кінцевим пунктами соціальноекономічного розвитку.

Постановка завдання. Метою даної статті є виявлення особливостей теоретичних підходів до визначення суттєвості людського капіталу, яка розглядає людей як засіб зростання інноваційної економіки, відмінно від концепції людського розвитку, де люди - основна ціль процесу.

Методологія. Методологічною основою дослідження $\epsilon$ сукупність загальнонаукових і спеціальних методів дослідження, серед яких необхідно виділити такі: методи аналізу та синтезу, діалектичний, системний - для дослідження теоретичних основ людського потенціалу; метод структурного функціонального аналізу - для розробки механізму формування та використання фінансового потенціалу інвестицій в інноваційну діяльність.

Результати дослідження. В сучасних умовах ідея про зростаючу роль людського капіталу в розвитку змісту й динаміки національної інноваційної системи стає визначальною для розуміння змін, які відбуваються в світовій і національній економіці. Це відображено в документах $\mathrm{OOH}$, щодо міжнародного стандарту в зведених показниках для визначення національного багатства, в яких людський капітал визначається як основний конкретно історичний економічний феномен соціально-економічного й науковотехнічного суспільного прогресу. За даними Всесвітнього банку і Програми розвитку $\mathrm{OOH}$ сьогодні на планеті накопичені матеріальні блага складають тільки $16 \%$ суспільного надбання, природні багатства - $20 \%$, людський капітал - $64 \%$. У національному багатстві розвинених країн людський капітал дорівнює від 70 \% до 80 \%. Внаслідок теорії людського капіталу укладання в людину сьогодні розглядається як джерело економічного зростання проти «звичайних» капіталовкладень. Встановлено, що протягом $\mathrm{XX}$ ст. накопичення людського капіталу випереджали темпи накопичення фізичного капіталу. За розрахунками американського вченого Е. Денісона приріст душового доходу у США за час післявійськового періоду був на $15-30 \%$ обумовлений підвищенням рівня освіти робочої сили.

За даними програми розвитку ООН індекс розвитку людського потенціалу в 2013-2014 pр. за рейтингом для розвинених країн складав 0,884 0,917, Україна за цим індексом посідала 83 місце з 185 країн, з рейтингом 0,734, Росія - 57 місце, з рейтингом - 0,778. Варто зауважити, що відповідно індексу глобальної конкурентоспроможності країн світу у 2014 р. Росія займала 53 місце з індексом 4,4, Україна 76 з індексом 4,1 із 144 країн світу 3 
min. індексом 2,8. Україна за інноваційною діяльністю (ефективність інновацій) у рейтингу країн випереджала Росію на 35 рангів (Україна 14 місце 3 рейтингом 0,90, Росія, відповідно 49, рейтинг - 0,79) [1, - с. ].

В економічній науці розвиток парадигми «людський капітал» являє собою процес нагромадження знання та наукових поглядів, виправдано можна віднести до епохи зародження капіталізму. Ця теорія, насамперед, пов'язана 3 науковими працями Уільяма Петті, Адама Смітта й Давіда Рікардо. Англійський статистик і економіст Уільям Петті першим зробив кількісне вимірювання людського капіталу, під яким він розумів живі діючі сили людини i пропонував їх вважати складовою частиною національного багатства країни, а також цінність основної маси людей, як і землі, рівна двадцятикратному річному доходу, який вони приносять [1, с. 82, 171]. Адам Сміт стверджував, що «праця була первісною ціною, загальною сумою, яка сплачена за усі речі. Ні золото чи срібло, а тільки праця була сплачена за усі нагромаджені багатства світу» [2, с. 38]. Д. Рікардо у роботі «Початок політичної економії і податкового обкладання» також розглядає загальний набір витрат на створення людського капіталу. Він підкреслював роль освіти у формуванні багатства нації: саме нестачею освіти у всіх шарах населення він роз'яснює різний рівень розвитку країн. Д. Рікардо вважав, що як і усі інші речі, труд має свою природну і свою ринкову ціни. Природна ціна праці - це та, яка необхідна, щоби робітники мали засоби існування, а також до продовження свого роду. Він стверджував, що 3 прогресом суспільства природня ціна праці має тенденцію підвищуватися. Ринкова ціна - це та, яка дійсно сплачується за неї відповідно до природної дії пропозиції до попиту (праця цінна, коли іiі мало й дешева, коли іiї удосталь) [3, с. 449].

Відомий український вчений M.I. Туган-Барановський відзначив своєрідність робочої сили як товару, який відрізняється від усіх інших товарів: «Решта товарів представляють зовнішні продукти або засоби господарської діяльності людини. Робоча сила людини це сама людина, тобто не об'єкт, а суб'єкт господарства» [4, с. 400].

Д.I. Менделєєв закарбував: Освіта $є$ благопридбаний капітал, який відповідає витратам часу і праці та накопиченню людської мудрості [5, с. 239].

Засновник кембріджської школи Альфред Маршалл допускав, що оцінка капітальної вартості людини може бути необхідна для досліджень праці. Йому належить ствердження, що саме корисний капітал це той, який вкладений в людські творіння. Вчений полягав, що хороша освіта принесе більше користі навіть звичайному працівнику. Він слушно спостерігає, що «доцільні витрати державних і приватних інвестицій на освіту не потрібно вимірювати лише безпосередньо практичними результатами. Економічна користь від використання значного промислового відкриття достатня до покриття витрат на освіту цілого міста» [6, с. 246]. 
Як самостійний напрямок економічного дослідження «теорія людського капіталу» була сформована тільки в 50-60-ті роки двадцятого століття завдяки роботам представникам «чикагської школи» Т. Шульца та Г. Беккера, Б. Вейсброда, Дж. Мінцера та інших. Термін «людський капітал» винайшов в 1960-х роках відомий американський економіст Теодор Шульц, лауреат Нобелівської премії 1979 р., щоби виразити вартість людського потенціалу. Т. Шульц показав, що людська здатність $є$ однією із форм капіталу. Він доводив, що в людський капітал, як в любий капітал можна здійснювати інвестиції. Як зазначає вчений у статті «Investment in Human Capital», «відмова розглядати людські ресурси як форму капіталу, як вироблені засоби виробництва, як результат інвестицій, сприяла збереженню класичного поняття праці, як можливості робити ручну роботу, що потребує небагато знань і навичок, можливостей, якою відповідно до цього поняття робочі наділені приблизно однаково» [7, с. 3]. Обгрунтовуючи необхідність інвестування у людський капітал для отримання доданої вартості у майбутньому, Т. Шульц концентрує увагу на п'яти основних напрямках: 1) медичні установи та послуги, включаючи всі витрати, які впливають на тривалість життя, витривалість, силу та життєздатність людей; 2) навчання за місцем роботи; 3) формальна освіта на початковому, середньому та вищому рівнях; 4) програми навчання, зокрема, в сільському господарстві; 5) міграція людей і сімей, щоби пристосуватися до зміни робочих місць. Крім освіти, зауважує Т. Шульц, треба і витрати в цю діяльність відносити до людського капіталу $[7$, с. 9]. За поглядом вченого, людські ресурси подібно, з одного боку, природним ресурсам, а 3 другого - матеріальному капіталу. Після народження людина, як і природні ресурси, не приносить ефекту. Тільки після відповідної «обробки» людина набуває якість капіталу. Тобто із зростанням витрат на підвищення якісного стану робочої сили праця як фактор поступово перетворюється в первинний людський капітал. Т. Шульц стверджував, що людський капітал - це форма капіталу, через те, що слугує джерелом майбутніх заробків або майбутніх задоволень. А людським він становиться тому, що він $\epsilon$ складовою частиною людини. Т. Шульц обгрунтував необхідність здійснення інвестицій в навчання та освіту, що сприятиме підвищенню рівня продуктивності праці працівників i, відповідно, збільшенню добробуту суспільства.

Концепцію людського капіталу Шульц використовував для аналізу і обгрунтування перспектив зростання країн. Він один із перших розрахував величину людського капіталу для США у 1961 р. На його думку основними результатами інвестицій в людину - $\epsilon$ накопичення здібностей людей до праці, їх ефективну творчу діяльність в суспільстві, підтримання здоров'я тощо. Він вбачав, що людський капітал володіє необхідними ознаками продуктивного характеру, який здатний нагромаджуватися та відтворюватися. 
За оцінками Т. Шульца, з виробленого в суспільстві валового продукту на накопичення людського капіталу використовується вже не 1/4 частини, як це випливало з більшості теорій відтворення XX ст., a 3/4 його загального розміру.

Мікроекономічний фундамент теорії людського капіталу був закладений лауреатом Нобелівської премії (1992р.) Гаррі-Стенлі Беккером, який теоретично довів, що людський капітал $є$ економічна категорія; виділив спеціальні та загальні інвестиції в людину; здійснив статистичний розрахунок економічної ефективності освіти; виконав перехід до загальних показників, що охоплюють весь життєвий цикл людини; виділив інвестиційні складові у поведінці агентів на ринку праці; ввів поняття «спеціальний людський капітал», який впливає на заповнення вакансій робочих місць і внутрішнього пересування за службою; отримав кількісні оцінки рентабельності вкладів в людину і порівняв їх з фактичною рентабельністю фірм США, що дозволило конкретизувати та розширити представлення інвестицій в людський капітал (у США в 60-і роки XX ст. рентабельність освіти на 10-15\% перевищувала рентабельність інших видів комерційної діяльності); обгрунтував необхідність визнання людського часу як ключового економічного ресурсу; пояснив структуру розподілу особистих доходів вікової динаміки заробітків, нерівності в оплаті чоловічої і жіночої праці тощо.

Г. Беккер, що особливо вагомо для реалізації соціальної політики, сформулював універсальну модель розподілу особистих доходів населення, яка грунтується на розподілі попиту й пропозиції інвестицій залежно від доходу сімей й природних здібностей шкільної молоді. 3 цього Беккер робить висновок, що родини, які залишають спадщину відраховують інвестиції в людський капітал в оптимальному розмірі, проти тих родин, які не залишають спадщини, частіше за все недоінвестують у їх навчання.

Ідеї, які закладені вченими у теорію людського капіталу, вплинули на переорієнтацію соціально-економічної політики держави. Завдяки цієї теорії змінились відносини суспільства до інвестицій у формування людини. У них навчились бачити інвестиції, по-перше, які забезпечують виробничий, до того ж довгостроковий за своїм характером ефект. Це сприяло на теоретичне обгрунтування прискореного розвитку освіти і підготовки кадрів у значних країнах світу. По-друге, соціальні програми почали розглядатися як ефективна боротьба з бідністю, завдяки перерозподілу доходів. Слід зазначити, що на тлі багатьох країн світу відносні показники бюджетних видатків на систему освіти України (в середньому 7,3 \% ВВП) виглядають непогано. Наприклад, у США цей показник у 2010 р. дорівнював 5,49 \% ВВП, у Німеччині - 5,08 \%, в Італії - 4,5\%, у Японії - 3,85 \% ВВП. Утім аналіз урядових видатків на освіту в грошовому виразі дає дещо іншу картину. У 2010 р. бюджетні видатки на освіту в Україні становили 10,78 млрд. дол. США, тоді як у США - 600,8 млрд. дол., у Японії - 125,8 млрд. дол., у Німеччині - 120,5 млрд. дол. Отже, 
Україна витрачає на освіту в 60 разів менше, ніж США, або в 12 разів менше ніж Японія чи Німеччина. Як результат середньорічні видатки на одного українського студента, що навчався за бюджетні кошти в 2010/2011 навчальному році, становили близько 2270 євро, тобто 51 \% таких видатків. У Естонії, котра має найменший показник серед країн-членів СС або $28 \%$ середнього по СС показника. Крім того, залишається низьким рівень оплати праці викладачів ВНЗ. Наприклад, український викладач у столиці отримає близько 4 тис. євро на рік, а в регіонах - лише близько 2,5 тис. євро [8, с. 84]. Не дивлячись на пафосні заяви щодо турбот за вчителями, їх заробітна плата залишається дуже низькою, а витрачає годин за рік більше. Наприклад, в Україні заробітна плата 3,6 тис. дол. США (навантаження - 880 год/рік); Швейцарія - 67 тис. дол. (750 год./рік), Німеччина - 65 тис. дол. (714 год./рік), Франція - 37 тис. дол. (618 год./рік), Чехія - 20 тис. дол. (750 год./рік), Фінляндія - 40 тис.дол. (550 год./рік), Росія - 5,1 тис.дол. (845 год./рік) [9, с.3].

Зростаюча роль людського капіталу у розвитку змісту й динаміки професіональної праці суспільного виробництва стає визначною для порозуміння радикальних змін, які відбуваються у світовій та національній економіках. Це відображено в документах $\mathrm{OOH}$, де пропонується міжнародний стандарт: «індекс розвитку людського капіталу», який свідчить щодо рівня життя, грамотності, освіченості і тривалості життя. Через це закономірно, що в Україні, яка знаходиться на етапі формування і розширення передумов постіндустріального суспільства економісти і вчені проводять активні дослідження за проблемою відтворення i розвитку людського потенціалу, особливостей його проявлення та функціонування в господарській діяльності. Не дивлячись на те, що історичні пріоритети в розробці теорії людського капіталу належать західній економічній думці, сучасна українська наука має свої незаперечні результати в дослідженні цієї проблеми. Людський капітал в українській економічній думці розглядається як конкретноісторичний феномен. Його суттєвими ознаками становляться дійсна спроможність відтворювати умови особистої свідомості індивіду, який охоплює як матеріально-речовинні, так і духовні блага, незалежно від того, виражені вони у вартісній формі або схожу можливість вони утримують у потенції. Людський капітал $\epsilon$ самовідтворювальною i репродуктивною категорією, під яким, розуміється втілений в людині запас здібностей, знань, навиків і мотивацій. Його формування подібно накопиченню фізичного або фінансового капіталів, потребує відтворення засобів від поточного споживання для отримання додаткових доходів у майбутньому. До важливих видів людських інвестицій відносять освіту, кваліфікаційну підготовку на виробництві, міграцію, інформаційний пошук, народження і виховання дітей. Людський капітал в економічних публікаціях розглядається в якості базового інноваційного джерела і ресурсу модернізації виробництва і економіки. При 
цьому підкреслюється, що особистість перетворює свої якості у капітал тільки при умовах самозростання його професійних знань разом із здійсненням творчої праці, реалізації розроблених інновацій. В цей капітал правомірно включаються процеси створення і реалізації нових ідей і наукових досягнень, освоєння знань і професій, підвищення кваліфікацій, реалізації нової техніки і технологій. В інноваціях проявляється економічна і соціальна активність людського капіталу. Тому, людський капітал завжди представляє міру можливостей людини надавати особистий доход через раціональне i послідовне використання у процесі трудової діяльності накопиченого потенціалу часу.

Кваліфіковані робітники, які необхідні сучасній інноваційній економіці, повинні не тільки розбиратися добре в техніці та технологіях, методах управління, але й також володіти інноваційними спроможностями, тобто вміти самостійно створювати інновації у процесі роботи, знаходити нове в зовнішньому світі у досвідах інших компаній, у відкриттях, винаходах та своєчасно використовувати все це у своїй компанії. Таким чином, важливою умовою діяльності таких робітників $\epsilon$ їх здатність до інноваційного мислення та інноваційного стилю трудової діяльності, тобто вміння постійно генерувати творчі ідеї та приймати нестандартні позитивні технічні рішення. Природно, вихідними показниками інноваційних здатностей робітників $\epsilon$ рівень їх професійної освіти і кваліфікації. Тому в засобах кадрового забезпечення робітників покладено механізм державного управління як процесом підготовки персоналу у плані освіти відповідно до потреб інноваційних процесів в економіці, так і процесом безперервного розвитку персоналу в зв'язку з розробкою та впровадженням інновацій на підприємствах. Тільки в цьому випадку будуть вирішені проблеми забезпечення економіки оптимально збалансованим за кількістю та якістю висококваліфікованим персоналом, а також формування в Україні інтелектуальної еліти, яка може вирішувати задачі, що стоять перед суспільством. Тому можна стверджувати, що людський капітал - це видима частина інтелектуального капіталу. Звідси виникають і нові вимоги до якості персоналу: цінується вміння отримувати та аналізувати інформацію 3 різних джерел, стимулюється адаптивність та креативність мислення співробітників, їх підприємницька спроможність та залученість, вміння працювати в командах та розвивати проектну діяльність, що безумовно буде відображатися на вдосконаленні інноваційної системи.

Вперше поняття «національна інноваційна система» в економічній літературі була запроваджена в 1987 р. Крисом Фримером вченим «Центру досліджень наукової політики» Сассекського університету, який провів дослідження формування технологічної політики Японії. Пізніше в 1992 р. датський вчений Б. Лундвалл опублікував дослідження 3 національної системи інновацій. 
Розпорядженням Кабінету Міністрів України від 17 червня 2003 р. № 680-Р була схвалена концепція розвитку національної інноваційної системи, яка орієнтувала розвиток економіки України за інноваційною моделлю розвитку. Відповідно до розпорядження, національна інноваційна система визначає взаємовідносини держави з недержавними корпоративними і приватними суб'єктами, які виробляють, розповсюджують, впроваджують та потребують інноваційні продукти та технології. Концепція національної інноваційної системи визначається економічними відносинами і зв'язками між агентами i інституціональними структурами, які обумовлені стадією становлення постіндустріального суспільства, в основі якого - інформаційні системи, високо розвинуті виробничі технології, які є результатом новітніх фізико-технічних i біологічних принципів. Вона включає як конкретних учасників інноваційного процесу, так і набір спеціальних умов, факторів, методів і принципів організації і стимулювання інноваційної діяльності.

Інноваційний попит, інновації і розвиток технологій є результатом таких взаємодій, при яких інноваційна ефективність економіки залежить від того, як організована така взаємодія в рамках формування і інституалізації системи, створення знання і інноваційного розвитку, а також від того, які технології використовуються. Разом 3 тим, інноваційна ефективність обумовлена взаємодією і взаємозалежністю національної системи і інноваційного попиту в тому чи іншому інституціональному середовищі. Розвиток техніки і технології впливає на культурні і суспільно-соціальні процеси. Все більш глибоким стає розуміння того, що соціально-економічні цілі в сучасних умовах можуть бути реалізовані тільки через інноваційний тип розвитку. Інноваційні досягнення повинні відповідати двом характеристикам: забезпечувати кількісний «стрибок» ефективності і якісні зміни iї структури; формувати новий засіб задоволення існуючих або щойно виникаючих потреб.

Проте, ключовим моментом в інноваційній реорганізації національної економіки $є$ пошук джерел фінансування для здійснення координації i стимулювання інноваційної діяльності усіх учасників інноваційного процесу, як власників інвестиційних ресурсів, так і виробників кінцевої продукції для внутрішнього i зовнішнього ринків. Інвестиційна політика, яка визначає пріоритети інвестиційних видатків зведеного бюджету за умов оптимізації інноваційних проектів, що фінансуються за рахунок коштів державного i місцевих бюджетів, сприятиме, по-перше, підвищенню ефективності бюджетних видатків, а по-друге, стимулює процеси виробництва та створює надійне підгрунтя для розвитку реального сектору економічного зростання та забезпечення фінансової стійкості України.

На сьогодні в Україні понад 50 \% капітальних інвестицій фінансується за рахунок власних коштів підприємств. Велике значення для фінансування інвестицій має позиковий капітал (понад $15 \%$ ). Державне фінансування 
інвестицій в Україні становить всього 6-7 \% загального обсягу інвестицій за результатами останніх років. Щодо обсягу іноземного інвестування, то їх частка не перевищує 3 \% загального обсягу інвестицій у основний капітал (табл. 1).

Таблиця 1

Капітальні інвестиції за джерелами фінансування в Україні у 2010-2013 pp., \%

\begin{tabular}{|l|c|c|c|c|}
\hline Джерело фінансування & 2010 & 2011 & 2012 & 2013 \\
\hline Державний бюджет & 5,8 & 7,1 & 5,8 & 2,4 \\
\hline Місцеві бюджети & 3,4 & 3,4 & 3,1 & 2,7 \\
\hline Власні кошти підприємств & 60,8 & 58,6 & 59,7 & 63,8 \\
\hline Кредити банків та інші позики & 12,3 & 16,3 & 17,1 & 15,3 \\
\hline Кошти іноземних інвесторів & 2,1 & 2,8 & 1,7 & 1,8 \\
\hline Інші джерела & 15,6 & 11,8 & 12,6 & 14,0 \\
\hline
\end{tabular}

Джерело: складено за даними Державної служби статистики (http: //www.ukrstat.gov.ua).

Концептуальні засади цієї політики вперше грунтовно розглянуто і сформовано на конференції ОOH із торгівлі та розвитку (UNCTAD) 2012 р. Метою такої політики на національному рівні є прискорення економічного зростання та підвищення конкурентоспроможності вітчизняного виробництва, шляхом досягнення синергетичного ефекту від проведення інноваційної діяльності та реалізації стратегії розвитку окремих галузей національної економіки.

Успішне рішення проблеми створення і реалізації інноваційної системи значною мірою залежить від вивчення і запозичення досвіду високо розвинутих країн, наприклад, США. В 1980 р. конгрес США прийняв закон Стівенсона-Уайдлера «Про технологічні інновації». Метою даного закону $\epsilon$ формування політики підвищення економічного, екологічного і соціального добробуту США шляхом:

- визначення інноваційної інфраструктури для вивчення технологій i стимулювання їх створення;

- сприяння розвитку технологій за допомогою створення наукових центрів сучасних досліджень;

- стимулювання підвищення використання розробок інноваційних, науково-технологічних рішень, які включають винаходи, програмне 
забезпечення і навчальні технології та фінансуються з державного бюджету на загальнодержавному, місцевому рівнях та приватному секторі;

- підтримання признання заслуг приватних суб'єктів і компаній, які зробили визначний вклад в розвиток технологій;

- проведення ротацій наукового і технологічного персоналу поміж університетами, промисловими і федеральними лабораторіями.

В законі Стівенсона-Уайдлера ставиться задача створення спеціального державного механізму управління інноваціями на довгостроковий період i обгрунтовані також основних складових цього механізму управління. Необхідно підкреслити, що дана ідея має наукову і практичну значимість i може бути використана для формування національної інноваційної політики. До якої треба віднести:

- спеціальну структуру управління інноваційною інфраструктурою, яка включає єдиний технологічний ланцюжок;

- спеціальну інформаційну службу наукових досягнень;

- центри спільних наукових досліджень;

- спеціальну структуру по політичному, національному та технікоекономічному контролю і аналізу реалізації інновацій з метою оцінки впливу їх на конкурентоспроможність країни.

В цілому, успішний світовий досвід формування ефективної інноваційної системи характеризується такими рисами:

- переформування традиційної лінійної моделі створення інновацій в ланцюгу «наукові дослідження - трансфер знань і технологій - інновація» до нелінійної моделі, яка передбачає складну систему взаємозалежностей вказаних елементів і орієнтацію інновацій не тільки на національний ринок, а й на глобальний;

- сприйняттям бізнесу, який виступає системним інтегратором науковотехнологічних і інвестиційних розробок, у процесі реалізації інноваційних проектів та, відповідно, підвищенням рівня інституцій, які забезпечують інтереси в інноваціях;

- врахуванням національних особливостей економічного і соціальноісторичного розвитку країни, які формують національну інноваційну систему, структура якої постійно транспортується відповідно новим реаліям, потребам і можливостям.

Нова парадигма в західних країнах в управлінні інноваціями вперше запропонована у 2003 році $Г$. Чесбро, професором каліфорнійського університету, грунтується на необхідності компаній відкривати інноваційні процеси для того, щоб використовуючи як внутрифірмові так і запозичені знання і технології, отримувати додаткову користь і перевагу [10]. Професор Г. Чесбро визначає відкриті інновації як використання внутрішніх і зовнішніх 
потоків знань 3 метою прискорення інноваційних процесів та розширювання ринків для передачі інновацій [11, с. 1].

Власне тому більшість компаній на сьогоднішній день почали використовувати практику відкритих інновацій (табл.2), сутність яких проявляється в тому, що інноваційний процес відбувається в рамках міжкорпоративних взаємозв'язків. Великі компанії виступають ініціаторами створення мережі знання, залучаючи для цього університети, незалежні приватні лабораторії, державні наукові структури тощо, а самі стають їх головною і домінантною ланкою.

Таблиця 2

Використання відкритих інновацій [12, с. 79]

\begin{tabular}{|l|c|}
\hline \multicolumn{1}{|c|}{ Види інноваційних компаній } & $\%$ \\
\hline $\begin{array}{l}\text { 1. Питома вага компаній, які здійснюють інноваційну діяльність } \\
\text { за методом відкритих інновацій }\end{array}$ & 42 \\
\hline $\begin{array}{l}\text { 2. Питома вага компаній, які здійснюють наукові дослідження } \\
\text { власними силами }\end{array}$ & 49 \\
\hline $\begin{array}{l}\text { 3. Питома вага компаній, які фінансують проведення наукових } \\
\text { досліджень і розробок сторонніми структурами }\end{array}$ & 21 \\
\hline $\begin{array}{l}\text { 4. Питома вага компаній, які здійснюють придбання знань у } \\
\text { формах ліцензій, винаходів, патентів тощо. }\end{array}$ & 24 \\
\hline
\end{tabular}

Узагальнюючи досвід розвинутих країн світу можна констатувати, що в умовах глобальної конкуренції на світовому ринку виграє не тільки той, хто має перспективні наукові запаси, але й той, хто володіє і використовує найбільш ефективний механізм інноваційної діяльності й розвиває ефективну інноваційну систему (насамперед розвинуту інноваційну інфраструктуру). Основними елементами інноваційної інфраструктури $є$ технопарки, венчурні фонди, центри колективного користування, трансфер технологій, бізнесінкубатори, інноваційно-технологічні та ліцензійні центри, структури бізнеснавчання тощо. В ідеальному вигляді інноваційна економіка повинна базуватися на пропорційному збалансованому розвитку фундаментальної і прикладної науки, вищої освіти й наукоємної промисловості. Власне так вона формується сьогодні на рівні розвинутих країн і міждержавних угрупувань.

Висновки. За результатами проведеного дослідження встановлено, що сучасна інноваційна модель економіки набуває нову форму: в іiі структурі визначною стає не матеріальна, а інтелектуальна власність. Провідна роль відводиться науково-технічному потенціалу, системі науково-дослідних розробок. Центральне місце в цій моделі займає людський капітал 3 його ідеями і можливостями, а інноваційні процеси змінюють не види діяльності, а їх технологічну можливість використовуючи в якості прямої продуктивної 
сили головну особливість людини - спроможність генерувати нове знання. Заміщення праці знаннями означає перехід від технічних навиків до інтелектуальних. Матеріальне виробництво в результаті технічних перетворень переміщується на другий план, а приоритетним стає інформаційний сектор, де інформації і знання перетворюються в провідну продуктивну силу, вирішальний фактор виробництва. В постіндустріальному суспільстві у результаті перетворень на зміну теорії трудової вартості приходить теорія вартості, яка створюється знаннями, пов'язаної 3 інноваціями, новаторством, впровадженням в процес виробництва досягнень HTP.

Наукова новизна проведеного дослідження полягає в обгрунтуванні змісту економічної категорії «людський капітал», як цілісного багатогранного явища, яке має структурно-функціональну форму організації, адекватне постіндустріальному стану суспільства інноваційної моделі економіки. Людський капітал - форма організації функціонування i розвитку продуктивних сил людини, яка включена в систему соціально-орієнтованої ринкової економіки в якості вирішального елемента суспільного відтворення і провідного фактора економічного зростання. Він включає знання, запас інформації, вміння, навики, досвід, професіоналізм, фізичне і духовне здоров'я, освіту, природні особливості і таланти, духовні якості, потенційні можливості, здатність людини до участі у процесі виробництва, яка у процесі взаємодії з іншими робітниками підприємства позитивно впливають на економічні результати.

Теоретичне та практичне значення результатів дослідження полягає в тому, що якщо економіка $\mathrm{XX}$ ст. мала технократичну направленість, то економіка XX ст. - це економіка знань. Не принижуючи можливості матеріальних ресурсів в діяльності підприємств, багато вчених сходяться на тому, що сьогодні капіталізація вартості підприємств формується під значним впливом нематеріальних ресурсів. Сьогодні людина розглядається не просто як індивідуум сам по собі, а у соціально-культурному аспекті, діючими у єдиній команді і об'єднаними на добровільних началах, в результаті чого у практиці менеджменту актуальним стає управління людиною як ресурсом. Це означає: відмову від зображення персоналу як дарового блага, яке не потребує витрат 3 боку адміністрації; усвідомлення проблеми дефіциту висококваліфікованих робітників i боротьба за їх притягнення; індивідуальний підхід до робітника виходячи з спільності інтересів компанії; аналіз та регулювання групових i індивідуальних інтересів, кадрового потенціалу, управління конфліктами, забезпечення вимог психофізіології, ергономіки тощо. Перетворювання робітників у головне джерело добробуту компанії змінює їх положення. Вони стали елементами людського капіталу головного надбання фірми та умови перемоги у конкурентній боротьбі. 
Перспективним напрямком подальших наукових досліджень визначено, що в сучасних умовах головною метою формування i функціонування національної інноваційної системи є процес інтеграції різних за цілями та задачами дослідницьких, виробничих та освітніх структур, які задіяні у сфері створення і промислового використання наукових знань і технологій.

\section{Лiтература:}

1. Петти У. Политическая арифметика (1676 г.) / Экономические и статистические работы. - М.: Государственное соц. - экономическое издательство, 1940. - 324 с.

2. Смит А. Исследование о природе и причинах багатства народов. - М.: Изд-во социально-экономической литературы, 1962. - $684 \mathrm{c}$.

3. Рикардо Д. Начала политической экономии // Антология экономической классики в 2х т. Т.1. - М.: МП «Эконов», 1993. -475 с.

4. Туган-Барановский М.И. Основы политической экономии. - М.: Российская политическая энциклопедия (РОССПЭН), $1998-664$ с.

5. Менделеев Д.И. Заветные мысли - Спб. 1903-1904. - 316 с.

6. Маршалл А. Основы экономической науки. - М.: Эксмо, 2007. - 832 с.

7. Schultz Theodore W. Investment in Human Capital / Schultz Theodore W. // The American Economic Review. - Vol.51 - №1 (Mar., 1961). - P. 1-17.

8. А.В. Козарезенко. Державно-приватне партнерство як інструмент фінансового регулювання розвитку людського потенціалу. Фінанси України № 2, 2014 р. С.79-93.

9. О. Онищенко. Себе миллиард, школе копейку - Зеркало недели, Украина 17 января 2014 г.

10. Chesbrough H.W. Open Innovation: The New Imperative for Creating and Profiting from Technology. - Boston, 2003.

11. Chesbrough H.W. New Puzzles and New Findings. In book: Open Innovation: Researching a New Paradigm / Ed. by H.V. Chesbrough, W. Vanhaverbeke, I. West. Oxford, 2006, P.1.

12. Сидакова С.С. Знания в современной парадигме инноваций / С.С. Сидакова - Вестник московского университета. Сер.6, Экономика, 2010 № 4, с.79.

\section{References:}

1. Petti U. Politicheskaja arifmetika (1676 g.) / Jekonomicheskie i statisticheskie raboty. M.: Gosudarstvennoe soc. - jekonomicheskoe izdatel'stvo, 1940. - 324

2. Smit A. Issledovanie o prirode i prichinah bagatstva narodov. - M.: Izd-vo social'nojekonomicheskoj literatury, 1962. $-684 \mathrm{~s}$.

3. Rikardo D. Nachala politicheskoj jekonomii // Antologija jekonomicheskoj klassiki v 2-h t. T.1. - M.: MP «Jekonov», 1993. - 475 s.

4. Tugan-Baranovskij M.I. Osnovy politicheskoj jekonomii. - M.: Rossijskaja politicheskaja jenciklopedija (ROSSPJeN), 1998 - 664 s.

5. Mendeleev D.I. Zavetnye mysli - Spb. 1903-1904. - 316 s.

6. Marshall A. Osnovy jekonomicheskoj nauki. - M.: Jeksmo, 2007. - 832 s.

7. Schultz Theodore W. Investment in Human Capital / Schultz Theodore W. // The American Economic Review. - Vol.51 - №1 (Mar., 1961). - P. 1-17.

8. A.V. Kozarezenko. Derzhavno-pryvatne partnerstvo iak instrument finansovoho rehuliuvannia rozvytku liuds'koho potentsialu. Finansy Ukrainy № 2, 2014 r. S.79-93. 
9. O. Onishhenko. Sebe milliard, shkole kopejku - Zerkalo nedeli, Ukraina 17 janvarja 2014 g.Chesbrough H.W. Open Innovation: The New Imperative for Creating and Profiting from Technology. - Boston, 2003.

10. Chesbrough H.W. Open Innovation: The New Imperative for Creating and Profiting from Technology. Boston, 2003.

11. Chesbrough H.W. New Puzzles and New Findings. In book: Open Innovation: Researching a New Paradigm / Ed. by H.V. Chesbrough, W. Vanhaverbeke, I. West. Oxford, 2006, P.1.

12. Sidakova S.S. Znanija v sovremennoj paradigme innovacij / S.S. Sidakova - Vestnik moskovskogo universiteta. Ser.6, Jekonomika, 2010 № 4, s.79. 